\title{
Sławomir GUŁKOWSKI ${ }^{1}$
}

\section{MODELOWANIE CHARAKTERYSTYK I-V OGNIW SŁONECZNYCH W ŚRODOWISKU MATLAB/SIMULINK}

\begin{abstract}
Pogarszająca się sytuacja energetyczna dzisiejszego świata skłania rządy wielu krajów do działań, związanych $\mathrm{z}$ poszukiwaniem alternatywnych rozwiązań w tym sektorze. Nowe, bardziej przyjazne środowisku technologie otrzymywania „czystej” energii mają szansę stać się w przyszłości poważną alternatywą dla paliw kopalnych, takich jak węgiel, ropa czy gaz, które są na wyczerpaniu. Bardzo obiecującym źródłem energii jest promieniowanie słoneczne, ze względu na jego wszechobecność i proekologiczność. Fotowoltaika jest jedną z najszybciej rozwijających się technologii konwersji energii ze źródeł odnawialnych z uwagi na niskie koszty utrzymania systemów. Czynnikiem hamującym powszechne wykorzystanie systemów fotowoltaicznych, jako źródła energii, sa jednak wciąż zbyt wysokie ceny modułów PV, na które składa się zarówno koszt materiałów bazowych jak i koszt technologii wytwarzania modułów. Jedną z metod wspomagających proces badań nad zwiększeniem sprawności przy jednoczesnym obniżeniu kosztów ogniw słonecznych jest modelowanie i symulacja komputerowa oparta na tzw. modelach zastępczych ogniw słonecznych. Jednym z takich modeli jest jednodiodowy model ogniwa słonecznego. Rezultaty obliczeń komputerowych wykonanych na podstawie modelu jednodiodowego pozwalają określić parametry pracy ogniwa przy różnych warunkach nasłonecznienia czy temperatury.

W artykule przedstawione zostały rezultaty dostosowania uniwersalnego modelu zastępczego ogniwa do przykładowego modułu komercyjnego KC32T02 oraz zaprezentowano wyniki obliczeń charakterystyk prądowo-napięciowych dla różnych warunków nasłonecznienia i temperatury. Otrzymane zależności są zgodne z wynikami podanymi przez producenta modułu.
\end{abstract}

Słowa kluczowe: fotowoltaika, ogniwa słoneczne, charakterystyka I-V, modelowanie komputerowe

\section{Wprowadzenie}

Podstawowe zjawisko fizyczne odpowiedzialne za wytworzenie energii elektrycznej w ogniwie fotowoltaicznym zaobserwowane zostało w XIX wieku. Chociaż już wówczas przewidywano zastosowanie na szerszą skalę pierwszych

\footnotetext{
${ }^{1}$ Sławomir Gułkowski, Politechnika Lubelska, Nadbystrzycka 38, 20-618 Lublin, tel. (+81) 53847 00, s.gulkowski@ pollub.pl
} 
ogniw w produkcji energii, to dopiero na początku lat pięćdziesiątych XX wieku wraz z rewolucją krzemową nastąpił znaczny przełom technologiczny w tej dziedzinie. Krzem jest obecnie najszerzej stosowanym materiałem do produkcji struktur stosowanych we współczesnych ogniwach fotowoltaicznych, ze względu na powszechność jego występowania, odpowiednią dla technologii PV przerwę energetyczną oraz nietoksyczność $[1,4]$. Maksymalne sprawności konwersji krzemowych ogniw krystalicznych mieszczą się w granicach 7 - 17\% dla krzemu polikrystalicznego oraz do $21 \%$ dla krzemu o strukturze monokrystalicznej.

\section{Budowa ogniwa słonecznego}

Rysunek 1 przedstawia schematycznie strukturę typowego ogniwa słonecznego. Wnętrze ogniwa stanowią dwa obszary: obszar typu p - baza oraz obszar typu $\mathrm{n}$ - emiter. Obszar p jest zwykle domieszkowany borem, a obszar $\mathrm{n}$ fosforem. Obszary w pobliżu kontaktów zawierają większą koncentrację domieszek niż w regionach $\mathrm{p}$ i n. Oznaczane są jako $\mathrm{p}+\mathrm{i} \mathrm{n}+$. Odpowiednio dobrany poziom domieszkowania zapobiega w ten sposób stratom ładunku na kontaktach. Obydwie powierzchnie ogniwa zawierają kontakty metaliczne.

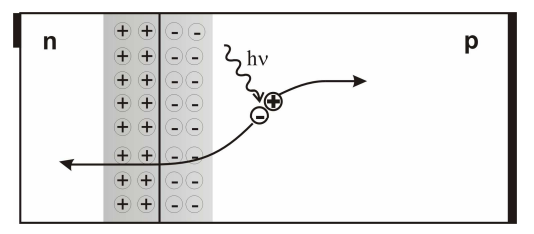

Rys. 1. Schemat struktury ogniwa słonecznego

Fig. 1. Scheme of the solar cell structure

Podstawą działania ogniwa słonecznego jest efekt fotowoltaiczny. Polega on na wygenerowaniu siły elektromotorycznej w wyniku oświetlenia złącza p-n [4]. Nie wszystkie fotony mają wystarczającą energię do uwolnienia elektronu z wiązań w krysztale półprzewodnika. Charakterystycznym parametrem wpływającym na efektywność fotokonwersji jest szerokość przerwy energetycznej. Jeśli na obszar złącza p-n pada foton o energii większej od wielkości przerwy energetycznej krzemu, traci tą energię na rzecz kreacji pary ładunków dziura elektron. Ładunki w wyniku działania pola elektrycznego wzdłuż złącza zostają rozdzielone a następnie wędrując przez ogniwo osiągają kontakty metaliczne. Jeżeli obwód jest zamknięty to będzie w nim płynął prąd elektryczny. Energia słoneczna jest zatem w ogniwie zamieniana na energię elektryczną w sposób czysto elektronowy, bez udziału jakichkolwiek reakcji chemicznych [1-3]. 


\section{Modelowanie charakterystyk I-V}

W przypadku idealnego ogniwa charakterystyka I-V może być opisana wzorem [6]:

$$
I=I_{p h}-I_{o}\left(\exp \left(\frac{q V}{k T}\right)-1\right),
$$

gdzie $k$ to stała Boltzmana, $T$ - temperatura w Kelwinach, $q(>0)$ - ładunek elektronu, $V$-napięcie na zaciskach ogniwa, $I_{0}$ - prąd nasycenia.

$I_{p h}$ jest generowanym fotoprądem związanym z padającymi na ogniwo fotonami. Jak pokazano na rysunku 2 ogniwo słoneczne może być modelowane za pomocą układu składającego się ze źródła prądu $I_{p h}$ oraz równolegle połączonej diody. Jej zadaniem w obwodzie jest uwzględnienie zjawiska rekombinacji w obszarze quasi-neutralnym ogniwa [6]. Bardziej dokładny od prezentowanego jest model dwudiodowy, w którym uwzględnia się również zjawisko rekombinacji w obszarze zubożonym.

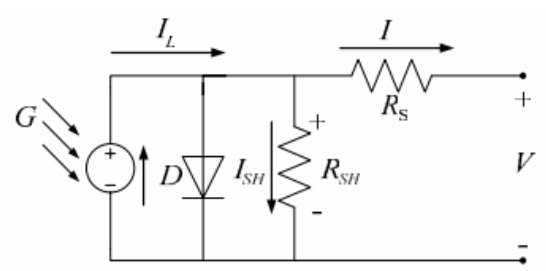

Rys. 2. Obwód zastępczy ogniwa słonecznego, na podstawie [5]

Fig. 2. Equivalent electrical circuit of the solar cell, based on [5]

W obwodzie przedstawionym na rysunku 2 uwzględnione zostały również tzw. rezystancje pasożytnicze $R_{S} i R_{S H}$ wpływające na końcowy kształt charakterystyki a wiec także na efektywność ogniwa. Uwzględniając powyższe parametry równanie (1) będzie miało postać:

$$
I=I_{p h}-I_{o}\left(\exp \left(\frac{q\left(V+I R_{S}\right) / n k T}{k T}\right)-1\right)-\frac{\left(V+I R_{S}\right)}{R_{S H}}
$$

gdzie $n$ jest współczynnikiem jakości złącza i przyjmuje wartości pomiędzy 1 a 2 . W przypadku ogniw dobrej jakości rezystancja $R_{S H}$ jest dużo mniejsza niż $R_{S}$ i zazwyczaj jest pomijana w obliczeniach.

$\mathrm{W}$ oparciu o rozwiązania przedstawione $\mathrm{w}$ pracy [5] a także następujące wartości współczynników: $n=1.2$ oraz $G=1000 \mathrm{~W} / \mathrm{m}^{2}$ równanie (2) po obliczeniach może być zapisane w następującej postaci: 


$$
I=I_{p h}-I_{0} \cdot\left[\exp \left(\frac{q\left(\frac{V}{36}+0.0079 \cdot I\right)}{n k T}\right)-1\right]
$$

gdzie

$$
I_{0}=0.000000022 \cdot\left(\frac{T}{298}\right)^{2.5} \cdot \exp \left[\frac{-1.12 \cdot q}{1.2 \cdot k} \cdot\left(\frac{1}{T}-\frac{1}{298}\right)\right]
$$

oraz

$$
I_{p h}=3.8+0.0024 \cdot(T-298) \text {. }
$$

Należy zwrócić uwagę, że w równaniu (3) natężenie prądu $I$ występuje zarówno z lewej jak i z prawej strony równania. W celu rozwiązania równania (3) posługujemy się iteracyjną metodą Newtona, następującej postaci:

$I^{n+1}=I^{n}-\frac{f(I)}{f^{\prime}(I)}$, gdzie $I^{n+1}, I^{n}, f^{\prime}(I)$ oznaczają odpowiednio wartość natężenia w następnym kroku iteracyjnym, bieżącą wartość natężenia wartość oraz pochodną funkcji $f(I)$. Iteracje rozpoczyna się od $I=0$.

Funkcja $f(I)$ oraz jej pochodna będą miały postać (6) i (7):

$$
\begin{gathered}
f(I)=I_{L}-I-I_{0} \cdot\left[\exp \left(\frac{q\left(\frac{V}{36}+0.0079 \cdot I\right)}{n k T}\right)-1\right] \\
f^{\prime}(I)=-1-I_{0} \cdot\left[\exp \left(\frac{q\left(\frac{V}{36}+0.0079 \cdot I\right)}{n k T}\right)-1\right] \cdot \frac{0.0079 \cdot q}{n k T} .
\end{gathered}
$$

Dokonując implementacji równań (3)-(7) w środowisku Matlab/Simulink otrzymuje się wykres charakterystyki I-V dla danego parametru T. Na podstawie wykresu można określić podstawowe parametry pracy ogniwa a zatem także wpływ temperatury pracy modułu na efektywność przetwarzania energii słonecznej w elektryczną. Analogicznie można określić równania modelu w celu zbadania wpływu nasłonecznienia na końcowy kształt charakterystyki I-V.

\section{Rezultaty obliczeń i ich analiza}

W tabeli 1 przedstawione zostały parametry modułu Kyocera KC32T02. Na podstawie parametrów dokonano implementacji modelu w środowisku Ma- 
tlab/Simulink oraz przeprowadzono obliczenia charakterystyk I-V modułu w funkcji temperatury i nasłonecznienia. Rezultaty obliczeń przedstawiono na rysunkach 3-4.

Tabela 1. Specyfikacja modułu KC32T02 [7]

Table 1. Specification of the KC32T02 module [7]

\begin{tabular}{|c|c|}
\hline MODEL & KC32T02 \\
\hline Moc & $32 \mathrm{~W}$ \\
\hline Vm & $17.4 \mathrm{~V}$ \\
\hline $\mathrm{Im}$ & $1.84 \mathrm{~A}$ \\
\hline Voc & $21.7 \mathrm{~V}$ \\
\hline Isc & $1.99 \mathrm{~A}$ \\
\hline
\end{tabular}

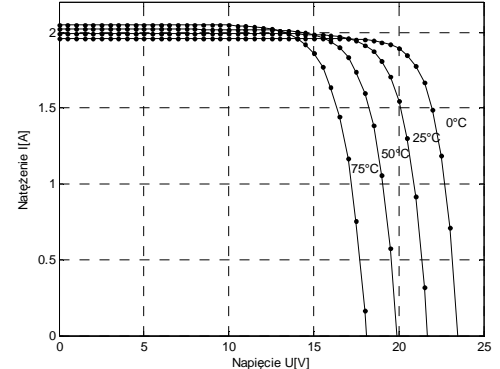

Rys. 3. Obliczone charakterystyki modułu I-V w funkcji temperatury

Fig. 3. Module characteristic calculated as a function of temperature

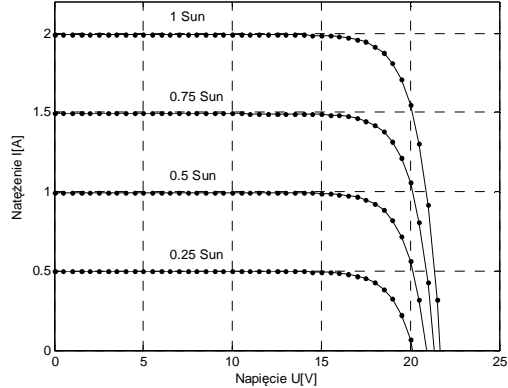

Rys. 4. Obliczone charakterystyki modułu I-V w funkcji nasłonecznienia

Fig. 4. Module characteristic calculated as a function of irradiance

W oparciu o rezultaty obliczeń przedstawione na rysunkach można określić parametry pracy modułu dla różnych warunków nasłonecznienia oraz temperatury modułów. W konsekwencji oznacza to możliwość określenia zmiany mocy generowanej przez system fotowoltaiczny w przypadku zmiany wartości nasłonecznienia a także określenie mocy generowanej przez system w funkcji temperatury.

\section{Podsumowanie}

W artykule przedstawiono komputerową metodę otrzymywania charakterystyk I-V modułu słonecznego w oparciu o jednodiodowy model zastępczy ogniwa. Do symulacji wybrano komercyjny moduł Kyocera KC32T02. Model komputerowy ogniwa zaimplementowany został w środowisku Matlab/Simulink z uwzględnieniem technicznych parametrów wybranego modułu. Rezultaty obliczeń pokazują zmianę przebiegu charakterystyki I-V modułu dla różnych 
warunków natężenia promieniowania słonecznego oraz dla różnych temperatur modułu.

\title{
Literatura
}

[1] E. Klugmann ,E. Klugmann-Radziemska. Ogniwa i moduły fotowoltaiczne oraz inne niekonwencjonalne źródła energii. Wydawnictwo Ekonomia i Środowisko, Białystok 2005.

[2] W. Lewandowski. Proekologiczne źródła energii odnawialnej. WNT, Warszawa 2005.

[3] Z. Jarzębski. Energia słoneczna. Konwersja fotowoltaiczna. PWN, Warszawawa 1990.

[4] J. M. Olchowik. Cienkie warstwy w strukturach baterii słonecznych. Wydawnictwo Politechniki Lubelskiej, Lublin, 2006.

[5] F. M. Gonzalez-Longatt. Model of Photovoltaic Module in Matlab. 2do Congreso Iberoamericano de Estudiantes de Ingeniería Eléctrica, Electronica Y Computation, II CIBELEC 2005

[6] T. Markvart, L. Castaner. Practical Handbook of Photovoltaics. Fundamentals and Applications. Elsevier, USA, 2003.

[7] http://www.kyocera.com.sg/products/solar/pdf/kc32t02.pdf [dostęp: maj 2014]

\section{MODELING OF THE I-V CHARACTERISTICS OF SOLAR MODULE IN MATLAB/SIMULINK ENVIRONMENT}

\begin{abstract}
S u m m a r y
The world energy situation force the governments of many countries to find alternative solutions in this sector. New, more environmentally friendly technologies of producing energy have a big potential to become alternative technique for producing energy from coal, petroleum or gas. Very promising source of energy is Sun. Photovoltaics is the one of the highest growth potential method of producing energy from renewable sources because of the low maintenance cost of the system. However, the price of modules are still high because of the cost of obtaining very pure silicon substrates for the solar cells. For this reason many researches focus on the increasing efficiency of the solar cells with decreasing the cost of production.

One of the method is computer modeling of I-V curve of solar cell with use of one-diode model. Results of computer analysis allow to obtain optimal parameters of the module for different environmental conditions. This paper presents modeling of I-V power output characteristics of solar module with use of PV one-diode cell equivalent circuit. Computational model has been implemented in Matlab/Simulink environment. On the basis of the model and parameters of the module delivered by manufacturer computer calculations of the I-V curves has been carried out. Results presented in this paper have shown possibility of behavior prediction of solar module in different weather condition, especially for varying cell temperature and solar radiation.
\end{abstract}

Keywords: photovoltaics, solar cell, I-V characteristics, computer modeling.

DOI: $10.7862 / \mathrm{rb} .2014 .88$

Przestano do redakcji: 07.12.2014 $r$.

Przyjęto do druku: 18.12.2014 r. 